Potravinarstvo Slovak Journal of Food Sciences vol. 15, 2021, p. 776-783

https://doi.org/10.5219/1677

Received: 28 July 2021. Accepted: 1 September 2021. Available online: 28 September 2021 at www.potravinarstvo.com (C) 2021 Potravinarstvo Slovak Journal of Food Sciences, License: CC BY 4.0

ISSN 1337-0960 (online)

\title{
DEVELOPMENT OF NUTRITIONAL MEALS AND GRUELS FROM BLENDS OF PRO-VITAMIN A CASSAVA GRITS AND AFRICAN YAM
}

\author{
Ololade Abosede Olodude, Victoria Funmilayo Abioye, Yetunde Mary Iranloye
}

\begin{abstract}
The potentials of underutilized African yam bean (AYB) and pro-vitamin A cassava in the development of nutritious food products with acceptable sensory properties were studied. Grits were produced from freshly harvested yellow root provitamin A cassava by peeling, washing, cutting, soaking, dewatering, roasting, sieving, and milling to obtain yellow root cassava grits while AYB flour was obtained by cleaning, roasting, dehulling, milling, and sieving ( $425 \mu \mathrm{m})$. A simple lattice design was used to obtain formulations of blends $(100: 0 ; 90: 10 ; 80: 20 ; 70: 30 ; 60: 40$ and $0: 100)$ of yellow root cassava grits and AYB flour. Gruels were prepared from these formulations using 4:5 w/v in boiling water while meals were prepared using 1:1 w/v of blend in boiling water for $5 \mathrm{~min}$. Moisture, fat, ash, protein, crude fibre, carbohydrate, $\beta$-carotene and calorific content of the blends were in the ranges of $4.66-7.92 \%, 2.20-2.82 \%, 2.16-2.66 \%, 2.72-20.43 \%, 1.15-1.40 \%$, $68.65-83.23 \%, 1.33$ to $3.97 \mu \mathrm{g} / \mathrm{g}$ and $348.37-358.96 \mathrm{kcal} / 100 \mathrm{~g}$, respectively. Saponin, tannin, trypsin inhibitor, hemagglutinin, starchyose, raffinose, phytate and Hydrogen Cyanide ranged from $0.039-0.087 \%, 0.11-0.15 \%, 1.24-3.15$ $\mathrm{mg} / \mathrm{g}, 1.47-3.49 \mathrm{mg} / 100 \mathrm{~g}, 1.51-1.81 \%, 0.38-0.45 \%, 0.82-2.69 \mathrm{mg} / \mathrm{g}, 0.07-4.47 \mathrm{mg} / \mathrm{kg}$, respectively. The sensory evaluation revealed that the meal and the gruel samples had acceptable sensory attributes. The developed products have the potentials in alleviating the problem of protein malnutrition in developing countries.
\end{abstract}

Keywords: Cassava; grits; legume; malnutrition; Gruel

\section{INTRODUCTION}

Cassava (Manihot esculenta Crantz), commonly referred to as manioc, tapioca, or yuca, is a tropical food crop primarily grown for its starchy tuberous roots and consumed as staples for more than 800 million people (Ikegwu et al., 2009; Vincenza et al., 2016). It is mostly consumed in some parts of Africa, Asia and America (Burns et al., 2010). Cassava thrives in low-nutrient and drought-prone environments making it a food security crop especially in developing countries (Nyerhovwo, 2004; Vinduranga, 2018; Shackelford et al., 2018). Common cassava food products include flour, confectionaries, starch, and gari (Osunde and Fadeyibi, 2011; Aniedu, Aniedu and Nwakor, 2012).

African Yam Bean (Sphenostylis stenocarpa) is a legume, hard to cook, and underutilized (George, Obilana and Oyeyinka, 2020) with a lot of nutritional advantages (Adegboyega et al., 2020). It is mostly cultivated for its tubers in the Central African Republic, Zaire, East Africa, and Ethiopia while the seeds are mostly cultivated in Southeastern Nigeria (Ndidi et al., 2014). A large variation and different accessions of African yam bean have been reported recently (Aremu and Ibirinde, 2012; Abioye, Olanipekun and Omotosho, 2015; Ajibola and Olapade,
2016; Baiyeri, Uguru and Ogbonna, 2018; Aina et al., 2020). The AYB seed is rich in protein and previous reports indicated values ranging between 19 and 30 percent (George, Obilana and Oyeyinka, 2020) and the amino acid profile is similar or even better than that of soybeans in terms of lysine and methionine (Obiakor, 2008; Atinuke, 2015). AYB seeds contain high dietary fiber, carbohydrate, and essential minerals such as phosphorus, calcium, iron, zinc, magnesium, potassium (Abioye, Olanipekun and Omotosho, 2015; Ajibola and Olapade, 2016; Ojuederie and Balogun, 2017; Anya and Ozung, 2019). However, it is underutilized due to the characteristic hardness of its seed coat which increases the processing cost and cooking time (Ene-obong and Okoye, 2007; Iwuchukwu et al., 2017), anti-nutritional factors in high concentration (Oboh et al., 1998; Ajibade et al., 2006; Fasoyiro et al., 2006; Adegboyega et al., 2020), beany flavor and the tendency to cause flatulence in humans (Machuka and Okeola, 2000; Ngwu, Aburime and Ani, 2014).

Yellow root Cassava bio-fortification has been developed primarily to help in reducing the prevalence of vitamin A deficiency where cassava is consumed as a staple food. It can be transformed into retinol within a human body, and this bioconversion can contribute to the reduction of vitamin 
A deficiency diseases (VAD) among the vulnerable groups. Vitamin A deficiency (VAD) is common in impoverished tropical nations, and it is especially prevalent in SubSaharan Africa. (Maziya-Dixon et al., 2004; Getu et al., 2017). Dependence on cassava diets has also been implicated in protein deficit challenges. Consumers who depend solely on cassava and cassava products for their protein sources with few or no high-protein food sources as supplements are at risk of protein malnutrition. More than a few studies have been published in fortification of cassava flour and cassava food products with protein sources such as cowpea (Oyarekua, 2009; Agbon, Ngozi and Onabanjo, 2010; Pedhuru, Tuarira and Mutetwa, 2017; Maziya-dixon et al., 2017), cassava leaf (Pedhuru, Tuarira and Mutetwa, 2017), soybean (Rokeya et al., 2011; Ajani et al., 2016; Maziya-Dixon et al., 2017), groundnut flour (Ajani et al., 2016), African yam bean (Ogbonnaya, Onumadu and Nwogu, 2018; Ajibola and Olapade, 2019).

Hence, there is scanty information on the development of nutritious food products from yellow root cassava grits and AYB flour blends. Therefore, this study aimed at developing nutritious food products with acceptable sensory attributes from yellow root cassava grits and African yam bean seeds flour which could increase the potentials of these crops and also improve the protein intake of the populace where cassava is consumed as a major staple food.

\section{Scientific Hypothesis}

This project was carried out to determine the effects of processing and combination of African yam bean and yellow root cassava on the chemical and antinutritional properties of the blends. It also determined the effects of the combination on the sensory properties of the food products.

\section{MATERIAL AND METHODOLOGY \\ Samples}

Yellow root cassava tuber (UMUCASS 37 variety) used for this research was procured from the Teaching and Research Farm of Ladoke Akintola University of Technology, Ogbomoso, Oyo State, Nigeria. Nigeria. The AYB seeds were bought at an indigenous market and identified at the LAUTECH teaching and research farm.

Cassava grits were produced from yellow root cassava using the method of Sanni and Jaji (2003) Grits were produced from freshly harvested yellow root pro-vitamin A cassava by peeling, washing, cutting, soaking (72 h, $28 \pm 2$ ${ }^{\circ} \mathrm{C}$ ), dewatering, roasting $\left(120^{\circ} \mathrm{C}\right)$, sieving and milling to obtain yellow root cassava grits while AYB flour was obtained as described by Aniedu and Aniedu (2014) by cleaning, roasting $\left(190^{\circ} \mathrm{C}, 10 \mathrm{~min}\right)$, dehulling, milling and sieving $(425 \mu \mathrm{m})$. Simplex lattice design was used to obtain different formulations from blends of yellow root cassava grit and AYB flour. The formulations were done with $(60-$ $100 \%)$ cassava grit and $(0-40 \%)$ AYB flour, while $100 \%$ AYB flour and $100 \%$ cassava grits were used as controls. The blends were thoroughly mixed for about 20 minutes using a Kenwood mixer (Model: Chef XL KVL4100S, made in China) to achieve uniform blending.

Gruel samples were prepared from different blends of yellow root cassava grit fortified with AYB flour as described by Ngwu, Aburime and, Ani (2014). Four hundred grams ( $400 \mathrm{~g}$ ) of each blend was reconstituted with 500 milliliters of water, and 2 liters of water was used to bring it to boil reconstituted flour was progressively added to the hot water while continually whisking to avoid lumps. The mix was left to simmer for around five (5) minutes while being constantly stirred until it was done.

The meal was prepared from different blends of yellow root cassava grit and AYB flour as described by Aniedu and Aniedu (2014). The blends were reconstituted into meals by cooking 100 grams of each of the blends in hundred (100) $\mathrm{mL}$ of boiling water while stirring vigorously for 5 minutes.

\section{Laboratory Methods}

The proximate composition of the blends was determined as described by the Association of Official Analytical Chemists (AOAC, 2010). Carbohydrate content was determined by difference AOAC (2010). Calorific content was calculated using the values obtained for carbohydrate, fat, and protein values. The $\beta$-carotene of the flour mixes was estimated using Rodriguez-Amaya and Kimura (2004) method that uses acetone extraction for carotenoid analysis. Tannin was determined with the method based on the fact that tannin-like substances in an alkaline solution diminish phosphotungstomolybdic acid, resulting in a strongly colored blue solution as devised by Adegunwa, Alamu and Omitogun (2011), Spectrophotometer was used to measure the absorbance at 760 (AA Analyse Perkin Nerma)/ Phytate was determined according to AOAC (2010). Kakade et al. (1974) technique was employed in the determination of trypsin inhibitors. Absorbance reading was taken at $410 \mathrm{~nm}$ with a spectrophotometer (AA Analyse Perkin Nerma). The hydrogen cyanide concentration was determined using the method of Alkaline picrate calorimetric while a spectrophotometer was then used to measure the absorbance of elutes from the standard and the sample at $510 \mathrm{~nm}$. (Mburu, Swaleh and Njue, 2013). Raffinose and Stachyose (oligosaccharides) were both determined with HPLC techniques (František et al., 1995). The mobile phase used was demineralized water in a reverse phase HPLC (RP-HPLC) and on a Silica C18 column.

\section{Sensory evaluation of the food products}

Sensory attributes of the cooked gruel and meal samples were carried out using a 9-point hedonic scale preference test. A total number of 50 panelists were used and to effectively compare the sensory ratings between the panelists, the panelists were semi-trained. Panelists were given coded samples of meal and gruel and asked to assess the items on a 9-point hedonic scale. (where one represents dislike significantly, and (nine) represents like significantly) for sensory attributes such as flavor, color, consistency, mouthfeel, texture, appearance, taste, and overall acceptability. On the panel were staff and students from the Ladoke Akintola University of Technology's Department of Food Science and Engineering in Ogbomoso, Oyo State, Nigeria.

\section{Description of the Experiment \\ Number of samples analyzed: 1 \\ Number of repeated analyses: 1 \\ Number of experiment replication: 1}




\section{Statistical analysis}

Data obtained were analyzed using Analysis of variance (ANOVA) while the means were separated using Duncan's multiple range test (DMRT), a significance level of 5\% was considered.

\section{RESULTS AND DISCUSSION \\ Chemical composition}

The proximate components of yellow root cassava grits and AYB seed flour blends are indicated in Table 1. The values obtained for the moisture varied between 4.66 to 7.92 percent and a significant $(p<0.05)$ difference was observed in each of the blends except in the blends that had 10-30\% of AYB flour substitution. The roasted AYB flour had the least moisture content which was close to $4.88 \%$ reported by Ndidi et al. (2014) for roasted AYB flour. All of the formulations had low moisture content which could be enough to have long storage when packaged in moistureproof materials. The fat content of the samples varied significantly $2.20-2.82 \%$ with the highest fat content in the $100 \%$ yellow root cassava grits $(2.82 \%)$. The values obtained were close to the value reported by Eleazu and Eleazu (2012) for yellow root cassava. The total ash (minerals) ranged from 2.16 to $2.66 \%$ and the highest value was recorded with roasted AYB flour which is close to the report of Ndidi et al. (2014). The protein level of the blended samples ranged between 2.72 and $20.43 \%$, with the highest inclusion of roasted AYB flour having the highest protein content. Significant differences $(p<0.05)$ were recorded among the blends, validating the fact that AYB contributed significantly to the protein composition of the blends. This backs up prior research that shows leguminous plants are good sources of nutrients, including a diverse spectrum of minerals and amino acids (Fagbemi, Oshodi and Ipinmoroti, 2004; Maphosa and Jideani, 2017). The crude protein content of the yellow root cassava grits was consistent with previous observations that cassava root food products are low in protein and that its consumption in meals necessitates the addition of adequate amino acids supplement (Burrell, 2003; Esonu, 2006; Olugbemi, Mutayoba and Lekule, 2010; Ngiki, Igwebuike and Moruppa, 2014). The crude fibre of the samples ranged from 1.15 to $1.40 \%$. Higher fibre content was recorded in flour blends with AYB flour substitution and was significant though the values were lower than the values reported. This could be as a result of the processing method used to process African yam beans into flour. The carbohydrate contents of the blended samples were in the range of 68.65 and $83.23 \%$. These samples' high carbohydrate readings are attributable to the carbohydrate content of their basic raw materials, especially the yellow root cassava tubers (El-sahy and Siliha, 2008; Awoyale et al., 2015).

The beta-carotene of the yellow root cassava grits and AYB flour blends is as shown in Fig 3. It ranged between 1.33 and $3.97 \mu \mathrm{g} / \mathrm{g}$, the hundred percent yellow root cassava grit had the highest amount of beta-carotene due to the variety of the cassava used, which was enriched with betacarotene. The value falls within the reported range by Eyinla et al. (2019) for food products from yellow root cassava. The blended samples also recorded some amounts of beta-carotene, which is a vitamin A precursor. As the substitution of AYB flour increased, the value of beta- carotene of the blended sample decreased. Consumption of these food products can contribute to the source of vitamin $\mathrm{A}$ in the diets of the people where cassava is their major staples. There were significant $(p<0.05)$ differences among the blends.

\section{Antinutritional factors}

Saponin levels of the blends ranged between 0.039 to $0.087 \%$. The results are consistent with those obtained by previous researchers for processed African yam beans. (Ajibola and Olapade, 2016: Anya and Ozung, 2019). The least value was observed in $100 \%$ yellow cassava grits while the sample with $100 \%$ AYB flour had the highest. This is a pointer to the fact that African yam bean contains some anti-nutrients. Saponins bind to iron, zinc, calcium, and vitamins to create insoluble mineral complexes, rendering them inaccessible (Samtiya, Aluko and Dhewa, 2020). There have been reports that processing such as roasting reduced the saponin content in African yam beans (Onyeike and Omubo-Dede, 2002; Ojuederie, Ajiboye and Babalola, 2020). Indicating that the low levels of saponin recorded in the roasted African yam bean were traceable to the effect of heat on the anti-nutrient. It has been found that low quantities of saponins in beans are not harmful to health, but larger concentrations in the diet can be poisonous at about $\geq 150 \mathrm{mg} / \mathrm{kg}$ body weight (Samtiya, Aluko and Dhewa, 2020).

Tannin content was in the range of 0.14 to $0.15 \%$, and in all of the blends, there were no significant changes in the tannin level. For AYB flour, the results were lower than those reported by Anya and Ozung (2019) for AYB (0.31 - 0.34\%). Tannins are high-molecular-weight $(>500)$, water-soluble phenolic chemicals that can precipitate protein, particularly pepsin (Adamczyk et al., 2017). Studies have shown that tannins are concentrated in the seed coat of legume seeds and are heat resistant. Indicating that the dehulling of the seed coat in the processing method reduced the tannin content in African yam bean flour. Tannin consumption of $1.5-2.5 \mathrm{~g}$ per day in the diet is considered safe (Sharma et al., 2019).

Therefore, the tannin level found in this study should not have any detrimental effects associated with tannins, such as antagonistic competition reducing accessible protein. Trypsin inhibitor content was in the range of 1.24 and 3.15 $\mathrm{mg} / \mathrm{g}$. The values are within the range of $2.22-3.05$ reported by Ajibola and Olapade (2016) for processed AYB seeds.

Phytate concentrations of the flour blends were in the ranges of 0.82 and $2.69 \mathrm{mg} / \mathrm{g}$, and all the blended samples differed significantly $(p<0.05)$. In both animal and human nutrition, phytic acid has been recognized as the most potent antinutritional factor in foods and a source of mineral ion deficit (Grases, Prieto and Costa-Bauza, 2017). The low phytate contents suggest that minerals otherwise chelated by phytate can be much more available. Hydrogen cyanide levels are as shown in Fig 3; they ranged between 0.07 and $4.47 \mathrm{mg} / \mathrm{kg}$. Roasting and fermentation processes involved in the production of cassava grits reduced the hydrogen cyanide to safe levels. As indicated by the Joint FAO/WHO Expert Committee on Food Additives (JECFA), a codex level of $10 \mathrm{mg} \mathrm{HCN} / \mathrm{kg}$ body weight (10 ppm) in cassava flour does not cause severe toxicity. (WHO, 2004). 

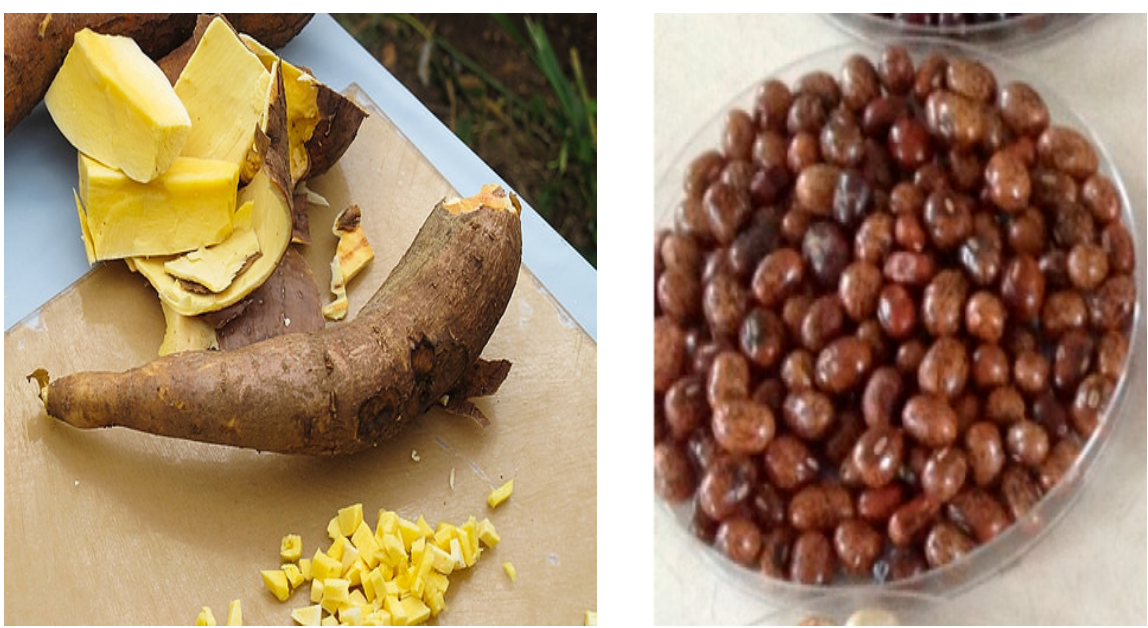

Figure 1 Yellow root cassava and African yam bean seeds.
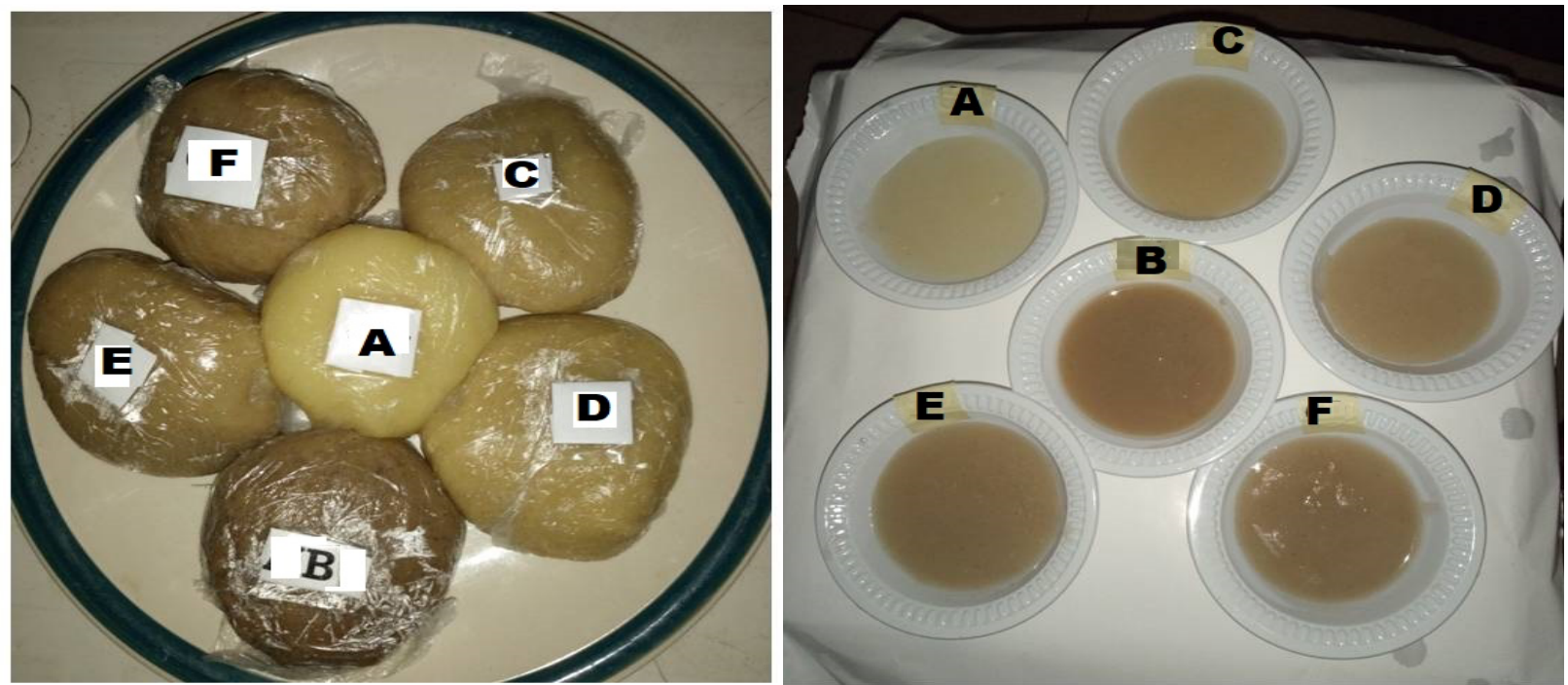

Figure 2 Meal and gruel samples prepared from blends of yellow root cassava grits and AYB flour.

Note: $\mathrm{A}=100 \%$ Yellow root cassava grit, $\mathrm{B}=100 \% \mathrm{AYB}$ flour, $\mathrm{C}=90 \%$ Yellow root cassava grit and $10 \% \mathrm{AYB}, \mathrm{D}=$ $80 \%$ Yellow root cassava grit and 20\% AYB, E $=70 \%$ Yellow root cassava grit and 30\% AYB, F $=60 \%$ Yellow root cassava grit and $40 \%$ AYB.

Indicating that the food products are within the safe level and will pose no hazard to the consumers.

Haemagglutin contents varied from 1.47 to $3.49 \mathrm{mg} / 100 \mathrm{~g}$. In this investigation, the flour blends containing 100 percent AYB flour had the highest hemagglutin level $(3.49 \mathrm{mg} / 100$ $\mathrm{g})$, which is lesser than the $5.30 \mathrm{mg} / 100 \mathrm{mg}$ reported by Ngwu, Aburime and Ani (2014) for roasted AYB.

Stachyose levels ranged from 1.51 to $1.81 \%$, while raffinose ranged from 0.38 to $0.45 \%$. The reduction of stachyose and raffinose in all the blended samples is of interest. This is because oligosaccharides (raffinose and stachyose) are implicated in flatulence and diarrhea.

\section{Sensory Evaluation}

The result of the sensory evaluation of gruel samples made with cassava grit and African yam bean flour mixes is as shown in Table 3 . All of the samples received good sensory ratings for all of the qualities, as well as overall acceptability. The panelists' ratings for the gruels' taste and flavor were not different significantly $(p>0.05)$ across all samples. In appearance, samples manufactured from $100 \%$ AYB flour and $20-30 \%$ AYB flour substitute did not differ substantially $(p<0.05)$. The sample created with 100 percent AYB flour and the samples manufactured with $10-$ 30 percent AYB flour had no discernible variation in general acceptability. but they varied significantly with the samples made from 100\% cassava grit and 40\% AYB flour substitution. The least score for color, consistency, mouth feels texture, and appearance was observed in the sample with $40 \%$ Substitution of AYB flour. The high mean scores observed for flavor, color, consistency, mouthfeel texture, appearance, taste, and overall acceptability indicated that all the gruel samples had acceptable sensory properties. as the percentage of substitution increased up to $30 \%$, the degree of similarity in all of the samples increased for practically all of the criteria. The high mean scores observed for appearance, color, hand feel, mouthfeel, mouldability, and overall acceptability indicated that all the meal samples were of good sensory attributes except the meal prepared from $100 \%$ AYB. The highest score for overall acceptability was observed in the sample with $70 \%$ yellow root cassava grits and 30\% AYB flour. 
Table 1 Proximate and calorific content of yellow root cassava grits and AYB flour blends.

\begin{tabular}{llllcccc}
\hline $\begin{array}{c}\text { Sample } \\
(\%)\end{array}$ & $\begin{array}{c}\text { MC } \\
(\mathbf{\%})\end{array}$ & $\begin{array}{c}\text { Fat } \\
\mathbf{( \% )}\end{array}$ & $\begin{array}{c}\text { Ash } \\
\mathbf{( \% )}\end{array}$ & $\begin{array}{c}\text { Protein } \\
\mathbf{( \% )}\end{array}$ & $\begin{array}{c}\text { Crude fibre } \\
(\mathbf{\%})\end{array}$ & $\begin{array}{c}\text { Carbohydrate } \\
(\mathbf{\%})\end{array}$ & $\begin{array}{c}\text { Calorific Content } \\
\mathbf{k c a l} / \mathbf{1 0 0} \mathbf{g}\end{array}$ \\
\hline $\mathbf{A}$ & $7.92^{\mathrm{d}}$ & $2.82^{\mathrm{c}}$ & $2.16^{\mathrm{a}}$ & $2.72^{\mathrm{a}}$ & $1.15^{\mathrm{a}}$ & $83.23^{\mathrm{c}}$ & 348.37 \\
$\mathbf{B}$ & $4.66^{\mathrm{a}}$ & $2.20^{\mathrm{a}}$ & $2.66^{\mathrm{f}}$ & $20.43^{\mathrm{f}}$ & $1.40^{\mathrm{f}}$ & $68.65^{\mathrm{a}}$ & 358.96 \\
$\mathbf{C}$ & $7.28^{\mathrm{c}}$ & $2.66^{\mathrm{b}}$ & $2.20^{\mathrm{b}}$ & $5.58^{\mathrm{b}}$ & $1.22^{\mathrm{b}}$ & $81.06^{\mathrm{c}}$ & 350.22 \\
$\mathbf{D}$ & $7.26^{\mathrm{c}}$ & $2.64^{\mathrm{b}}$ & $2.36^{\mathrm{c}}$ & $7.36^{\mathrm{c}}$ & $1.29^{\mathrm{c}}$ & $79.09^{\mathrm{c}}$ & 348.20 \\
$\mathbf{E}$ & $7.26^{\mathrm{c}}$ & $2.67^{\mathrm{b}}$ & $2.37^{\mathrm{c}}$ & $8.63^{\mathrm{d}}$ & $1.33^{\mathrm{d}}$ & $77.74^{\mathrm{b}}$ & 350.08 \\
$\mathbf{F}$ & $7.10^{\mathrm{b}}$ & $2.71^{\mathrm{b}}$ & $2.46^{\mathrm{d}}$ & $10.60^{\mathrm{e}}$ & $1.39^{\mathrm{e}}$ & $75.74^{\mathrm{b}}$ & 350.82 \\
\hline
\end{tabular}

Note: The mean values in the same column with varied superscripts are significantly different $(p<0.05)$. $\mathrm{A}=100 \%$ Yellow root cassava grit, $\mathrm{B}=100 \% \mathrm{AYB}$ flour, $\mathrm{C}=90 \%$ Yellow root cassava grit and $10 \% \mathrm{AYB}, \mathrm{D}=80 \%$ Yellow root cassava grit and $20 \% \mathrm{AYB}, \mathrm{E}=70 \%$ Yellow root cassava grit and $30 \% \mathrm{AYB}, \mathrm{F}=60 \%$ Yellow root cassava grit and $40 \%$ AYB.

Table 2 Anti-nutritional composition of the yellow root cassava grits and AYB flour blends.

\begin{tabular}{lccccccc}
\hline Sample & $\begin{array}{c}\text { Saponin } \\
\%\end{array}$ & $\begin{array}{c}\text { Tannin } \\
\%\end{array}$ & $\begin{array}{c}\text { Trypsin } \\
\text { Inhibitor } \\
(\mathbf{m g} / \mathbf{g})\end{array}$ & $\begin{array}{c}\text { Hemaglutin } \\
(\mathbf{m g} / \mathbf{1 0 0} \mathbf{g})\end{array}$ & $\begin{array}{c}\text { Stachylose } \\
\%\end{array}$ & $\begin{array}{c}\text { Raffinose } \\
\%\end{array}$ & $\begin{array}{c}\text { Phytate } \\
(\mathbf{m g} / \mathbf{g})\end{array}$ \\
\hline $\mathbf{A}$ & $0.039^{\mathrm{a}}$ & 0.14 & $1.24^{\mathrm{a}}$ & $1.47^{\mathrm{a}}$ & $1.79^{\mathrm{d}}$ & $0.45^{\mathrm{d}}$ & $0.82^{\mathrm{a}}$ \\
$\mathbf{B}$ & $0.087^{\mathrm{e}}$ & 0.15 & $3.15^{\mathrm{f}}$ & $3.49^{\mathrm{f}}$ & $1.81^{\mathrm{e}}$ & $0.45^{\mathrm{d}}$ & $2.69^{\mathrm{f}}$ \\
$\mathbf{C}$ & $0.050^{\mathrm{b}}$ & 0.11 & $1.28^{\mathrm{b}}$ & $2.14^{\mathrm{b}}$ & $1.51^{\mathrm{a}}$ & $0.38^{\mathrm{a}}$ & $1.07^{\mathrm{b}}$ \\
$\mathbf{D}$ & $0.060^{\mathrm{c}}$ & 0.12 & $1.35^{\mathrm{c}}$ & $2.42^{\mathrm{c}}$ & $1.55^{\mathrm{b}}$ & $0.39^{\mathrm{b}}$ & $1.19^{\mathrm{c}}$ \\
$\mathbf{E}$ & $0.062^{\mathrm{c}}$ & 0.13 & $1.91^{\mathrm{d}}$ & $2.69^{\mathrm{d}}$ & $1.75^{\mathrm{c}}$ & $0.44^{\mathrm{c}}$ & $1.40^{\mathrm{d}}$ \\
$\mathbf{F}$ & $0.065^{\mathrm{d}}$ & 0.14 & $2.14^{\mathrm{e}}$ & $3.03^{\mathrm{e}}$ & $1.79^{\mathrm{d}}$ & $0.45^{\mathrm{d}}$ & $1.62^{\mathrm{e}}$ \\
\hline
\end{tabular}

Note: The mean values of the same column with different superscripts differ by a significant amount $(p<0.05)$. $\mathrm{A}=100 \%$ Yellow root cassava grit, $\mathrm{B}=100 \% \mathrm{AYB}$ flour, $\mathrm{C}=90 \%$ Yellow root cassava grit and $10 \% \mathrm{AYB}, \mathrm{D}=80 \%$ Yellow root cassava grit and 20\% AYB, E =70\% Yellow root cassava grit and 30\% AYB, F $=60 \%$ Yellow root cassava grit and $40 \%$ AYB.

Table 3 Sensory evaluation of gruel samples produced from yellow root cassava grits and AYB flour blends.

\begin{tabular}{lccccccc}
\hline Sample & Flavour & Colour & Consistency & $\begin{array}{c}\text { Mouthfeel } \\
\text { Texture }\end{array}$ & $\begin{array}{c}\text { Appearance } \\
\text { Taste }\end{array}$ & $\begin{array}{c}\text { Overall } \\
\text { Acceptability }\end{array}$ \\
\hline A & $6.32^{\mathrm{a}}$ & $7.66^{\mathrm{d}}$ & $7.18^{\mathrm{d}}$ & $7.22^{\mathrm{c}}$ & $7.34^{\mathrm{c}}$ & $6.14^{\mathrm{a}}$ & $7.38^{\mathrm{c}}$ \\
$\mathbf{B}$ & $6.58^{\mathrm{a}}$ & $6.52^{\mathrm{bc}}$ & $5.76^{\mathrm{ab}}$ & $6.16^{\mathrm{ab}}$ & $6.56^{\mathrm{bc}}$ & $5.86^{\mathrm{a}}$ & $6.32^{\mathrm{b}}$ \\
$\mathbf{C}$ & $6.18^{\mathrm{a}}$ & $6.72^{\mathrm{bc}}$ & $6.70^{\mathrm{cd}}$ & $6.78^{\mathrm{bc}}$ & $6.34^{\mathrm{ab}}$ & $6.22^{\mathrm{a}}$ & $5.94^{\mathrm{b}}$ \\
$\mathbf{D}$ & $6.72^{\mathrm{a}}$ & $7.20^{\mathrm{cd}}$ & $6.24^{\mathrm{abc}}$ & $6.14^{\mathrm{ab}}$ & $6.62^{\mathrm{bc}}$ & $6.20^{\mathrm{a}}$ & $6.42^{\mathrm{b}}$ \\
$\mathbf{E}$ & $6.68^{\mathrm{a}}$ & $6.28^{\mathrm{cd}}$ & $6.36^{\mathrm{bc}}$ & $6.10^{\mathrm{ab}}$ & $6.60^{\mathrm{bc}}$ & $5.98^{\mathrm{a}}$ & $5.84^{\mathrm{b}}$ \\
F & $6.42^{\mathrm{a}}$ & $5.78^{\mathrm{a}}$ & $5.50^{\mathrm{a}}$ & $5.86^{\mathrm{a}}$ & $5.58^{\mathrm{a}}$ & $5.56^{\mathrm{a}}$ & $5.06^{\mathrm{a}}$ \\
\hline
\end{tabular}

Note: Mean values in the same column with different superscripts are considerably different from each other $(p<0.05)$. $\mathrm{A}=100 \%$ Yellow root cassava grit, $\mathrm{B}=100 \% \mathrm{AYB}$ flour, $\mathrm{C}=90 \%$ Yellow root cassava grit and $10 \% \mathrm{AYB}, \mathrm{D}=80 \%$ Yellow root cassava grit and $20 \% \mathrm{AYB}, \mathrm{E}=70 \%$ Yellow root cassava grit and $30 \% \mathrm{AYB}, \mathrm{F}=60 \%$ Yellow root cassava grit and 40\% AYB.

Table 4 Sensory evaluation of meal samples produced from yellow root cassava grits and AYB flour blends.

\begin{tabular}{lcccccc}
\hline Sample & Appearance & Colour & Hand feel & Mouthfeel & Mouldability & $\begin{array}{c}\text { Overall } \\
\text { Acceptability }\end{array}$ \\
\hline A & & & & & $6.14^{\mathrm{b}}$ & $6.84^{\mathrm{c}}$ \\
$\mathrm{B}$ & $7.60^{\mathrm{b}}$ & $7.52^{\mathrm{c}}$ & $7.04^{\mathrm{b}}$ & $6.62^{\mathrm{b}}$ & $3.56^{\mathrm{a}}$ & $3.42^{\mathrm{a}}$ \\
$\mathrm{C}$ & $5.48^{\mathrm{a}}$ & $6.36^{\mathrm{b}}$ & $4.22^{\mathrm{a}}$ & $3.86^{\mathrm{a}}$ & $6.62^{\mathrm{b}}$ & $6.60^{\mathrm{c}}$ \\
$\mathrm{D}$ & $7.08^{\mathrm{b}}$ & $6.68^{\mathrm{b}}$ & $6.54^{\mathrm{b}}$ & $6.52^{\mathrm{b}}$ & $6.52^{\mathrm{b}}$ & $6.34^{\mathrm{c}}$ \\
$\mathrm{E}$ & $7.04^{\mathrm{b}}$ & $6.64^{\mathrm{b}}$ & $6.76^{\mathrm{b}}$ & $6.70^{\mathrm{b}}$ & $7.64^{\mathrm{b}}$ & $7.80^{\mathrm{d}}$ \\
$\mathrm{F}$ & $8.26^{\mathrm{c}}$ & $7.80^{\mathrm{c}}$ & $8.02^{\mathrm{c}}$ & $7.80^{\mathrm{c}}$ & $6.20^{\mathrm{b}}$ & $5.50^{\mathrm{b}}$ \\
\hline
\end{tabular}

Note: The mean values in the same column with different superscripts vary significantly $(p<0.05)$. $\mathrm{A}=100 \%$ Yellow root cassava grit, $\mathrm{B}=100 \% \mathrm{AYB}$ flour, $\mathrm{C}=90 \%$ Yellow root cassava grit and $10 \% \mathrm{AYB}, \mathrm{D}=80 \%$ Yellow root cassava grit and $20 \% \mathrm{AYB}, \mathrm{E}=70 \%$ Yellow root cassava grit and $30 \% \mathrm{AYB}, \mathrm{F}=60 \%$ Yellow root cassava grit and $40 \%$ AYB. 


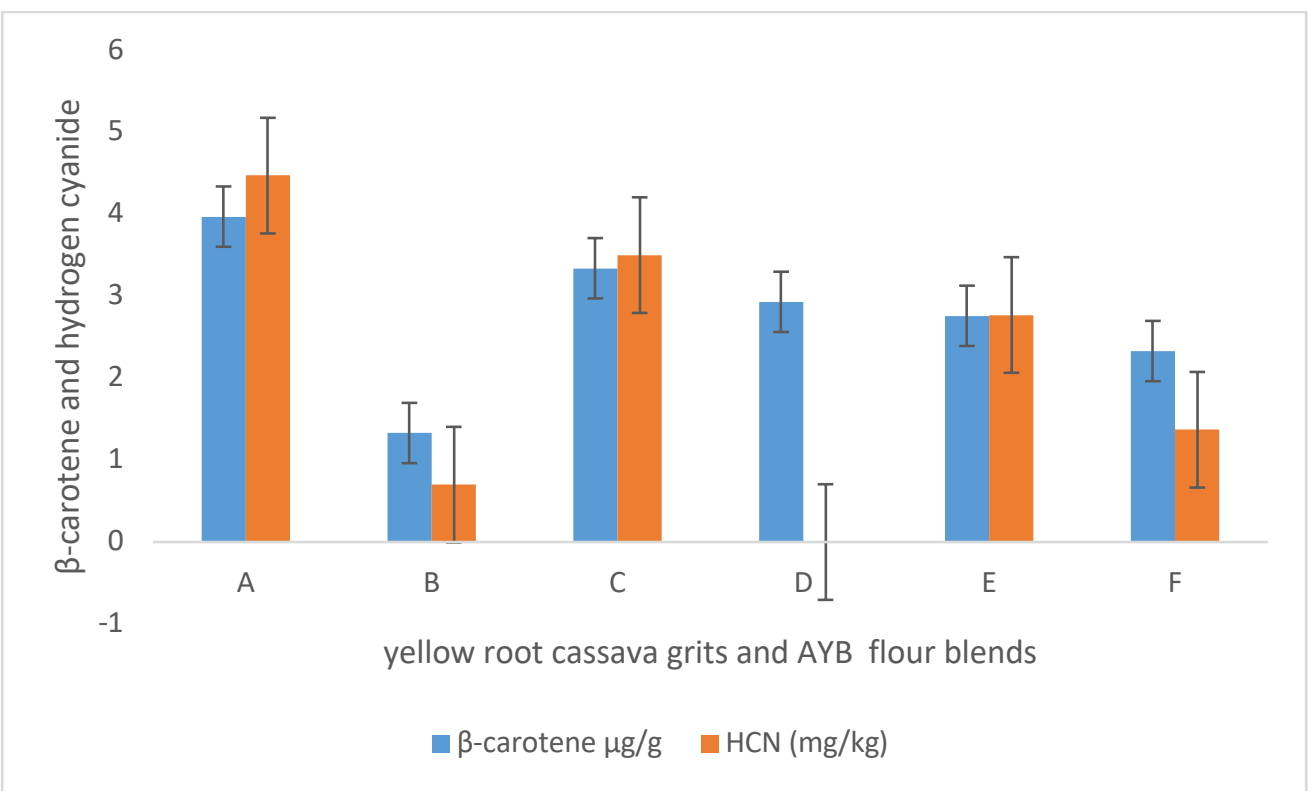

Figure 3 The $\beta$-carotene and the hydrogen cyanide contents of the yellow root cassava and AYB flour blends.

Note: $\mathrm{A}=100 \%$ Yellow root cassava grit, $\mathrm{B}=100 \% \mathrm{AYB}$ flour, $\mathrm{C}=90 \%$ Yellow root cassava grit and $10 \% \mathrm{AYB}, \mathrm{D}=$ $80 \%$ Yellow root cassava grit and $20 \% \mathrm{AYB}, \mathrm{E}=70 \%$ Yellow root cassava grit and $30 \% \mathrm{AYB}, \mathrm{F}=60 \%$ Yellow root cassava grit and $40 \%$ AYB.

\section{CONCLUSION}

This study has shown that nutritious gruel and meals with acceptable sensory properties can be obtained from blends of $80 \%$ cassava grits with $20 \%$ roasted AYB flour and $70 \%$ yellow cassava grit with $30 \%$ roasted AYB flour, respectively. The protein content and overall sensory characteristics of prepared meals and gruels were positively affected with AYB flour substitution. Hence, the potential of African yam bean in alleviating the problems of protein malnutrition in the developing world among the most vulnerable groups was established.

\section{REFERENCES}

Abioye, V. F., Olanipekun, B. F., Omotosho, O. T. 2015. Effect of varieties on the proximate, nutritional and antinutritional composition of nine variants of African yam bean seeds (Sphenostylis stenocarpa). Donnish Journal of Food Science and Technology, vol. 1, no. 2, p. 17-21.

Adamczyk, B., Simon, J., Kitunen, V., Adamczyk, S., Smolander, A. 2017. Tannins and their complex interaction with different organic nitrogen compounds and enzymes: old paradigms versus recent advances, Chemistry Open, vol. 6, no. 5, p. 610-614. https://doi.org/10.1002/open.201700113

Adegboyega, T. T., Abberton, M. T., AbdelGadir, A. H., Diand, A., M., Maziya-Dixon, B., Oyatomi, O. A., Ofodile, S., Babalola, O. O. 2020. Evaluation of nutritional and antinutritional properties of African yam bean (Sphenostylis stenocarpa (Hochst ex. A. Rich.) Harms.) Seeds. Journal of Food Quality. https://doi.org/10.1155/2020/6569420

Adegunwa, M. O., Alamu, E. O., Omitogun, L. A. 2011. Effect of processing on the nutritional contents of yam and cocoyam tubers. Journal of Applied Biosciences, vol. 46, p. 3086-3092.

Agbon, C. A., Ngozi, E. O., Onabanjo, O. O. 2010. Production and nutrient composition of fufu made from a mixture of cassava and cowpea flours. Journal of Culinary Science and Technology, vol. 8, no. 2-3, p. 147-157. https://doi.org/10.1080/15428052.2010.511096
Ademola, I. A., Christopher, O. I., Ukoabasi, O. E., Olaniyi, O., Daniel, P., Michael, T. A. 2020. Morphological characterisation and variability analysis of African yam bean (Sphenostylis stenocarpa Hochst. ex. A. Rich) Harms, International Journal of Plant Research, vol. 10. no. 3, p. 45-52.

Ajani, A. O., Alade, O. A., Olagbaju, A. R., Fasoyiro, S. B., Arowora, K. A., Oyelakin, M.O. 2016. Chemical and sensory qualities of stored gari fortified with soybean and groundnut flour. Applied Tropical Agriculture, vol. 21, no. 2, (Special Issue). p. 79-83.

Ajibade, S. R., Balogun, M. O., Afolabi, O. O., Ajomale, K. O., Fasoyiro, S. B. 2006. Genetic variation in nutritive and anti-nutritive content of African yam bean. Tropical Science, vol. 45, no. 4, p. 144-148. https://doi.org/10.1002/ts.14

Ajibola, G. O., Olapade, A. A. 2016. Physical, proximate and anti-nutritional composition of African yam bean (Sphenostylis stenocarpa) seeds varieties. Journal of Food Research; vol. 5, no. 2, p. 67-72. https://doi.org/10.5539/jfr.v5n2p67

Ajibola, G. O., Olapade, A. A. 2019. Physico-Chemical and functional properties of cassava and African yam bean flour blends, Applied Tropical Agriculture, vol. 24, no. 1, p. 200207.

Anya., M. I., Ozung, P. O. 2019. Proximate, mineral and antinutritional compositions of raw and processed African yam bean (Sphenostylis stenocarpa) seeds in cross river state, Nigeria. Global Journal of Agricultural Sciences, vol. 18, no. 1, p. 19-29. https://doi.org/10.4314/gjass.v18i1.3

Aniedu, C., Aniedu, O. C., Nwakor, N. 2012. Impact and adoption of value added innovations in root and tuber crops among farmers in Imo State, Nigeria. Global Journal of Science Frontier Research Agriculture and Veterinary Sciences, vol. 12, no. 11, p. 1-5.

Aniedu, C., Aniedu Onyemechi, C. 2014. Fortification of Cassava $f u f u$ flour with African yam bean flour: Implications for improved nutrition in Nigeria. Pelargia Research Library, Asian Journal of Plant Science and Research, vol. 4, no. 3, p. 63-66. 
A.O.A.C. 2010. Official method of Analysis 15th edition, Association of official Analytical Chemists, Willbehington DC.

Aremu, C. O., Ibirinde. D. B. 2012. Bio-diversity Studies on Accessions of African Yam Bean (Sphenostylis stenocarpa). International Journal of Agricultural Research, vol. 7, no. 2, p. 78-85. https://doi.org/10.3923/ijar.2012.78.85

Atinuke, A. 2015. Chemical composition and sensory and pasting properties of blends of maize-African yam bean seed. Journal of Nutritional Health and Food Science, vol. 3, no. 3, p. 1-6. https://doi.org/10.15226/jnhfs.2015.00146

Awoyale, W., Sanni, L. O., Shittu, T. A., Adegunwa, M. O. 2015. Effect of varieties on the functional and pasting properties of biofortified cassava root starches. Journal of Food Measure and Characterization, vol. 9, no. 2, p. 225-232. https://doi.org/10.1007/s11694-015-9227-6

Baiyeri, S. O, Uguru, M. I., Ogbonna, P. E., Samuel-Baiyeri, C. C. A., Okechukwu, R., Kumaga., F., Amoatev, K. 2018. Evaluation of the nutritional composition of the seeds of some selected African yam bean (Sphenostylis stenocarpa Hochst Ex. A. Rich (Harms). Agro-Science, vol. 17, no. 2, p. 37-44. https://doi.org/10.4314/as.v17i2.5

Burns, A., Gleadow, R., Cliff, J., Anabela, Z., Cavagnaro, T. 2010. Cassava: The drought, war and famine crop in a changing world. Sustainability, vol. 2, no. 11, p. 3572-3607. https://doi.org/10.3390/su2113572

Burrell, M. M. 2003. Starch: The need for improved quality or quantity-an overview. Journal of Experimental Botany, vol. 54, no. 386, p. 451-456. https://doi.org/10.1093/jxb/erg049

Eleazu, C. O., Eleazu, K. C. 2012. Determination of the proximate composition, total carotenoid, reducing sugars and residual cyanide levels of flours of 6 new yellow and white cassava (Manihot esculenta Crantz) varieties. American Journal of Food Technology, vol. 7, no. 10, p. 642-649. https://doi.org/10.3923/ajft.2012.642.649

El-Sahy, K. M., Siliha, H. 2008. Use of sulphite treated sweet potato flour in manufacturing of wheat bread. Getreide Mehl and Brot., vol. 42, no. 7, p. 215-217.

Ene-Obong, E. E., Okoye, F. I. 2007. Interrelationship between yield and yield components in Africa bean. Beitrage zur tropischen Landwirtschaft und Veterinarmedizin, vol. 30, p. 283-290.

Esonu, B. O. 2006. Animal Nutrition and Feeding: A Functional Approach. 2nd Edition, Owerri, Nigeria : Rukzeal and Ruksons Associates Memory Press.

Eyinla, T. E., Maziya-Dixon, B., Alamu, O. E., Sanusi, R. A. 2019. Retention of pro-vitamin A content in products from new bio-fortified cassava varieties. Foods, vol. 8, no. 5, p. 177. https://doi.org/10.3390/foods 8050177

Fagbemi, T. N., Oshodi, A. A., Ipinmoroti, K. O. 2004. Effect of processing and salt on some functional properties of some cashew nut (Anarcadum occidentalis) flour. Journal of Food, Agricultural and Environment, vol. 12, no. 2, p. 121-128.

Fasoyiro, S. B., Ajibade, S. R., Omole, A. J., Adeniyan, O. N., Farinde, E. O. 2006. Proximate, minerals and antinutritional factors of some underutilized grain legumes in South Western Nigeria. Nutrition and Food Science, vol. 36, no. 1, p. 18-23. https://doi.org/10.1108/00346650610642151

Food Safety Network. 2014. Cassava Nutritional Network. FSNET: University of Guelph, March 14. 2005; 2 pages.

František, K., Renata A., Juana, F., Keith, R. P., Pavel, K. 1996. A rapid HPLC method for the determination of raffinose family of oligosaccharides in pea seeds. Journal of Liquid Chromatograph and Related Technologies, vol. 19, no. 1, p.135-147. https://doi.org/10.1080/10826079608006294
Getu, B., Solomon, F. R., Chauhan, D, Solis, E .G., Narayanan, N., Gehan, J., Siritunga, D., Stevens, R. L., Jifon, J., Eck, J. V., Linsler, E., Gehan, M., Ilyas1, M., Fregene, M., Sayre, R. T., Anderson, P., Taylor, N. J ., Cahoon, E. B. 2017. Provitamin A biofortification of cassava enhances shelf-life but reduces dry matter content of storage roots due to altered carbon partitioning into starch. Plant Biotechnology Journal, vol. 16, no. 6, p. $2-47$. https://doi.org/10.1111/pbi.12862

George, T. T., Obilana, A. O., Oyeyinka, S. A. 2020. The prospects of African yam bean: past and future importance. Heliyon, vol. 6, no. 11, e05458. https://doi.org/10.1016/j.heliyon.2020.e05458

Grases, F., Prieto, R. M, Costa-Bauza, A. 2017. Dietary phytate and interactions with mineral nutrients. In Clinical aspects of natural and added phosphorus in foods, New York, NY : Springer. p. 175-183. https://doi.org/10.1186/s43014020-0020-5

Ikegwu, O. J., Nwobasi V. N., Odoh, M. O., Oledinma, N. U. 2009. Evaluation of the pasting and some functional properties of starch isolated from some improved cassava varieties in Nigeria. African Journal of Biotechnology, vol. 8, no. 10, p. 2310-2315.

Iwuchukwu, J. C., Nwobodo, C. E., Ezema, C. N, Udoye, C. 2017. Value addition activities and challenges of African yam bean (Sphenostylis stenocarpa) Farmers in Enugu State, Nigeria. Sustainability, Agric. Food and Environmental Research. vol. 5, no. 4. p. 42-65. https://doi.org/10.7770/saferV5N4-art1307

JECFA. 1993. Cyanogenic glycosides. In: Toxicological evaluation of certain food additives and naturally occurring toxicants. Geneva, World Health Organization, 39th Meeting of the Joint FAO/WHO Expert Committee on Food Additives (WHO Food Additives Series 30). Available at http://www.inchem.org/documents/jecfa/jecmono/v30je18.ht $\mathrm{m}$

Kakade, M. L., Rackis, J. J., Mcghene, J. E., Puski, G. 1974. Determination of trypsin inhibitor activity of soya products. Cereal Chemistry, vol. 51, no. 3, p. 376-381.

Maphosa, Y., Jideani, V. A. 2017. The Role of Legumes in Human Nutrition, Functional Food Improve Health through Adequate Food, Maria Chavarri Hueda, IntechOpen, https://doi.org/10.5772/intechopen.69127

Maziya-Dixon, B., Akinyele, I., Oguntona, E., Nokoe, S., Sanusi, R., Harris, E. 2004. Nigeria Food Consumption and Nutrition Survey 2001 2003. Summary Report, Ibadan, Nigeria.

Maziya-Dixon, B., Alamu, E. O., Popoola, I. O., Yomeni, M. 2017. Nutritional and sensory properties: Snack food made from high-quality cassava flour and legume blend. Food Science and Nutrition, vol. 5, no. 3, p. 805-811. https://doi.org/10.1002/fsn3.464

Mburu, F. W., Swaleh, S., Njue. 2013. Potential toxic levels of cyanide in cassava (Manihot esculenta Crantz) grown in Kenya. African Journal of Food Science, vol. 6, no. 16, p. 416420. https://doi.org/10.5897/AJFS12.058

Ndidi, U. S., Ndidi, C. U., Olagunju, A., Muhammad, A., Francis, G. B., Okpe, O. 2014. Proximate, antinutrients and mineral composition of raw and processed (Boiled and Roasted) Sphenostylis stenocarpa Seeds from Southern Kaduna, Northwest Nigeria. International Scholarly Research Notices, vol. 2014, Article ID 280837, 9 pages, 2014https://doi.org/10.1155/2014/280837

Ngiki, Y. U., Igwebuike, J. U., Moruppa S. M. 2014. Utilization of cassava products for poultry feeding. 
International Journal of Science and Technology, vol. 2, no. 6, p. 4.

Ngwu, E. K., Aburime, L. C., Ani P. N. 2014. Effect of processing methods on the proximate composition of African yam bean (Sphenostylis stenocarpa) flours and sensory characteristics of their gruels. International Journal of Basic And Applied Sciences, vol. 3, no. 3, p. 285-290. https://doi.org/10.14419/ijbas.v3i3.2927

Nyerhovwo, J. T. 2004. Cassava and the future of starch. Electronic Journal of Biotechnology, vol. 7, no. 1. https://doi.org/10.2225/vol7-issue1-fulltext-9

Obiakor, P. N. 2008. Effect of fermentation on the nutrient and antinutrient composition of African yam bean seeds and pearl millet grains. Annual conference and scientific meeting, Nutrition Society of Nigeria, vol. 30, p. 60-70.

Oboh, H. A., Muzquiz. M., Burbano, C., Cuadrado, C., Pedrosa, M. M., Ayet., G., Osagie, A. U. 1998. Anti-nutritional constituents of six underutilized legumes grown in Nigeria. Journal of Chromatography, vol. 82, p. 307-312. https://doi.org/10.1016/S0021-9673(98)00542-1

Ogbonnaya, M., Onumadu, K. S., Nwogu, O. G. 2018. Proximate composition and sensory evaluation of blends of cassava fufu, cooking banana (Musa saba) and African Yam Bean (Sphenostylis stenocarpa) composite flours and paste. Research Journal of Food Science and Quality Control, vol. 4, no. 1, p. $42-50$.

Ojuederie O. B and Balogun M. O. 2017. Genetic variation in nutritional properties of African yam bean (Sphenostylis Stenocarpa Hochst Ex. A. Rich. Harms) accessions. Nigerian Journal of Agriculture, Food and Environment, vol. 13, no. 1, p. $180-187$.

Ojuederie, O. B., Ajiboye, J. A., Babablola, O. O. 2020. Biochemical and histopathological studies of key tissues in health male Wistar rats fed on African yam bean seed and tuber meals. Journal of Food Quality. vol. 2020, Article ID 8892618, 10 pages, 2020. https://doi.org/10.1155/2020/8892618

Olugbemi, T. S., Mutayoba, S. K., Lekule, F. P. 2010. Effect of Moringa (Moringa oleifera) inclusion in cassava based diets fed to broiler chickens. International Journal of Poultry Science, vol. 9, no. 4, p. 363-367.

Onyeike, O., Dede, T. T. 2002. Effect of heat treatment on the proximate composition, energy values, and levels of some toxicants in African yam bean (Sphenostylis stenocarpa) seed varieties. Plant Foods for Human Nutrition, vol. 57, no. 3-4, p. 223-231. https://doi.org/10.1023/A:1021833516234

Osunde, Z. D., Fadeyibi, A. 2011. Storage methods and some uses of cassava in Nigeria. Continental Journal of Agricultural Science, vol. 5, no. 2, p. 12-18.

Oyarekua, M. A. 2009. Co-fermentation of cassava/cowpea/carrot to produce infant complementary food of improved nutritive quality. Asian Journal of Clinical Nutrition, vol. 1, no. 3, p. 120-130. https://doi.org/10.3923/ajen.2009.120.130

Pedhuru, R., Tuarira, M., Mutetwa, M. 2017. Cassava fortification and quality evaluation, Journal of Aridland Agriculture, vol. $\quad 3, \quad$ p. $\quad 35-40$. https://doi.org/10.25081/jaa.2017.v3.3364

Rodriguez-Amaya, D. B., Kimura, M. 2004. HarvestPlus handbook for carotenoid analysis. Washington, Cali: International Food Policy Research Institute International Center for Tropical Agriculture (CIAT). p. 58.

Rokeya, B., Sudip, K. R., Mahfuzur., S. M., Rahman, S. M. 2011. Protein fortification and use of cassava flour for bread formulation. International Journal of Food Properties, vol. 14, no.1, p.185-198. https://doi.org/10.1080/10942910903160406
Samtiya, M., Aluko, R. E., Dhewa, T. 2020. Plant food antinutritional factors and their reduction strategies: an overview. Food Production Processing and Nutrition, vol. 2, p. 6. https://doi.org/10.1186/s43014-020-0020-5

Sanni, L. O., Jaji, F. F. 2003. Effect of drying and roasting on the quality attributes of $f u f u$ powder. International Journal of Food Properties, vol. 6, no. 2, p. 230-231. https://doi.org/10.1081/JFP-120017843

Shackelford, G. E., Haddaway, N. R., Usieta, H. O., Pypers, P., Petrovan, S. O., Sutherland, W. J . 2018. Cassava farming practices and their agricultural and environmental impacts: a systematic map protocol. Environmental Evidence, vol. 7, no. 30. https://doi.org/10.1186/s13750-018-0142-2

Sharma, K., Kumar, V., Kaur, J., Tanwar, B., Goyal, A., Sharma, R., Gat, Y., Kumar, A. 2019. Health effects, sources, utilization and safety of tannins: A critical review, Toxin Reviews, https://doi:org/10.1080/15569543.2019.1662813

Viduranga, Y. W. 2018. Introductory Chapter: Cassava as a Staple Food, Cassava, Viduranga Waisundara, IntechOpen, https://doi.org/10.5772/intechopen.70324

Vincenza, F., Clara, P., Keith, T., Manuela, E. P. 2016. Cassava (Manihot esculenta Crantz) and yam (Dioscorea spp.) crops and their derived foodstuffs: safety, security and nutritional value. Critical Reviews in Food Science and Nutrition, vol. 56, no. 16, p. 2714-2727. https://doi.org/10.1080/10408398.2014.922045

WHO. 2004. Programme on ChemicalS: Hydrogen cyanide and cyanides: human health aspects. Geneva: World Health Organization; 2004.

WHO. 2017. World Heallth Organization. Micronutrient deficiencies. Available http://www.who.int/nutrition/topics/Vadlen

Funds:

This research received no external funding.

Acknowledgments: -

Conflict of Interest:

The authors declare no conflict of interest.

Ethical Statement:

This article does not contain any studies that would require an ethical statement.

\section{Contact Address:}

Ololade Abosede Olodude, Ladoke Akintola University of Technology, Ogbomoso, Faculty of Food and Consumer Science, Department of Food Science, P.M.B.4000, Oyo State, Nigeria. Tel. +2348062180429,

E-mail: vfabioye@lautech.edu.ng

ORCID: https://orcid.org/0000-0001-6393-8838

*Victoria Funmilayo Abioye, Ladoke Akintola University of Technology, Ogbomoso, Faculty of Food and Consumer Science, Department of Food Science, P.M.B.4000, Oyo State, Nigeria. Tel. +2348062180429,

E-mail: vfabioye@lautech.edu.ng

ORCID: https://orcid.org/0000-0002-5425-0027

Yetunde Mary Iranloye, Landmark University Omu-Aran, Kwara State, Nigeria College of Agricultural Sciences, Department of Food Science and Nutrition,

E-mail: iranloye.yetunde@lmu.edu.ng

ORCID: https://orcid.org/0000-0002-8313-5001 